\title{
Cr AND Ni SIMULTANEOUS PHYTOTOXICITY AND MUTAGENICITY ASSAY
}

\author{
AGÁTA FARGAŠOVÁ, JANA LIŠTIAKOVÁ \\ Department of Ecosozology and Physiotactics, Faculty of Natural Sciences, Comenius \\ University in Bratislava, Mlynská dolina, SK-842 15 Bratislava, Slovak Republic \\ (fargasova@fns.uniba.sk)
}

\begin{abstract}
For genotoxicity study simultaneous phytotoxicity and mutagenicity assay with Vicia sativa L. var. Klára was used. For phytotoxicity the following rank orders of growth inhibition can be arranged: for roots: $\mathrm{Ni}(\mathrm{II})>\mathrm{Cr}(\mathrm{VI})>\mathrm{Cr}(\mathrm{III})$; for shoots: $\mathrm{Ni}(\mathrm{II})>\mathrm{Cr}(\mathrm{VI}) \geq \mathrm{Cr}$ (III). For mutagenicity assay root tips of $V$. sativa were used and chromosome aberrations were determined at least in 500-anatelophases. All tested metals exerted in $V$. sativa a significant increase of chromosomal aberration rate in applied concentrations. Maximum of aberrations invoked $\mathrm{Cr}(\mathrm{VI})$ and the rank order of aberrations fall was: $\mathrm{Cr}(\mathrm{VI})>\mathrm{Ni}(\mathrm{II})>$ $\mathrm{Cr}(\mathrm{III})$. Genotoxic effects of metals were determined by analysis of micronuclei frequency in the pollen tetrads of Tradescantia plants. None of tested metal significantly stimulated micronuclei frequency and genotoxic effect was decreased in order: $\mathrm{Cr}(\mathrm{VI}) \geq \mathrm{Ni}(\mathrm{II})>\mathrm{Cr}(\mathrm{III})$.
\end{abstract}

Key words: chromium, nickel, Vicia sativa, phytotoxicity, chromosomal aberation assay, Tradescantia micronucleus assay

\section{Introduction}

Vascular plants have been found to be highly effective for recognizing and predicting metal stress in the environment (growth inhibition, reduction of biomass production, changes in water absorption and translocation) (SHANKER et al., 2005; SZÁRAZOVÁ et al., 2008). For genotoxicity studies are plants highly responsible and sensitive. Their beneficial interest is that seeds and pollen grains can be easy storage away and offer cheap, relative easy and accurate toxicological assessment (KRISTEN, 1997). By their ability to accumulate toxic substances, they indicate metal presence in the environment even in very low concentration (CHANDRA, 2004).

Contamination of soil and water by $\mathrm{Cr}$ and $\mathrm{Ni}$ are of particular recent concern. The impact of $\mathrm{Cr}$ contamination on the physiology of plants depends on the metallic species responsible for its mobilization, uptake and toxicity in the plant system (BENNICELLI et al., 2004). While Cr is not considered an essential element for plant nutrition (SHARMA et al., 1995), Ni is classified an essential trace element (BROWN et al., 1987); and although it is found everywhere in the environment, it usually occurs only in trace amounts.

\section{Materials and methods}

Simultaneous phytotoxicity and mutagenicity assay was carried out on plant species Vicia sativa L. var. Klára according to MIADOKOVÁ et al. (2005). After $24 \mathrm{~h}$ of soaking at $25^{\circ} \mathrm{C}$ in distilled water or solution with metal concentration equal to $\mathrm{IC}_{50}$ value the seeds of $V$. sativa were allowed to germinate in Petri dishes (diameter $=18.5$ 
$\mathrm{cm}$ ) with filter paper soaked with the same concentration of tested metal as that used for soaking. Phytotoxicity was assayed after $72 \mathrm{~h}$ of the dark cultivation in the thermostat at $25{ }^{\circ} \mathrm{C}$ by the same way as described previously SVETKOVÁ and FARGAŠOVÁ (2007) for S. alba. The roots and shoots of $V$. sativa seedlings were measured and the growth inhibition percentage was assessed. The seedling roots used for chromosome and genome mutability evaluation were fixed and permanent slides were prepared by the Feulgen method. Chromosome aberrations were determined at least in 500-anatelophases. For statistic analysis the Student's t-test was used.

The procedures for maintaining the Tradescantia plants and for analyzing micronuclei frequency in the tetrads have been described by MIŠÍK et al. (2006; 2007). Tradescancia paludosa clone 03 was standardly cultivated at the Department of Botany, Faculty of Natural Sciences, Comenius University in Bratislava. Inflorescence were harvested at the 8-10-buds stage and immersed into $500 \mathrm{ml}$ of tested metal solutions $\left(100 \mathrm{mg} / \mathrm{CrO}_{3}\right.$ and $\left.\mathrm{NiCl}_{2}, 1000 \mathrm{mg} / \mathrm{l} \mathrm{Cr}\left(\mathrm{NO}_{3}\right)_{3}\right)$ for $12 \mathrm{~h}$. As control tap water was used. The $24 \mathrm{~h}$ reconvalescence, during which inflorescence peduncles were dipped in $500 \mathrm{ml}$ of tap water, succeeded to $12 \mathrm{~h}$ exposure. Then the buds were fixed for $24 \mathrm{~h}$ in ethanol : acetic acid $(3: 1)$. The fixed material was stored in $70 \%$ ethanol. Slides were prepared from the fixed material using the aceto-carmine squash technique. Micronuclei were scored in the early tetrad stages of pollen mother cells. In the present study, 15 to 20 inflorescences comprised a sample. Three hundred tetrads were scored from each of five slides prepared from a treatment sample for a total of 1,500 tetrads per plot. Data were recorded as the number of micronuclei (MCN) per 100 tetrads. A change of frequency of MCN/100 tetrads was considered statistically significant (at $\mathrm{P}<0.05$ ) if the difference between the mean of the control population and the mean of the treated population was at least twice as large as the standard error of the difference between the two means (MA et al., 1994; MIŠÍK et al., 2007).

For samples of tested metals $\mathrm{NiCl}_{2} \cdot 6 \mathrm{H}_{2} \mathrm{O}, \mathrm{Cr}\left(\mathrm{NO}_{3}\right)_{3} \cdot 9 \mathrm{H}_{2} \mathrm{O}$ and $\mathrm{CrCO}_{3}$ of analytical grade p.a. were obtained from Lachema, Brno, Czech Republic.

All experiments for growth inhibition were set up in a completely randomized design with three replicates. Chronic toxicity was assessed as inhibition of roots and shoots growth and results were evaluated by Gryck-Haustein method and $\mathrm{IC}_{25}, \mathrm{IC}_{50}$ and $\mathrm{IC}_{75}$ concentrations were determined. The results were statistically evaluated by using Toxicity program.

\section{Results and discussion}

Toxic effects of heavy metals, mainly during chronic exposure, are not visible immediately hence ecotoxicological studies request also assessment of genotoxicity. Genotoxicological effect is developed then the concentration is low order than that for fytotoxicity effect (MIČIETA and MURÍN, 1998). For phytotoxicity and clastogenicity study $V$. sativa seedlings were used. Phytotoxicity was determined through $\mathrm{IC}_{25}, \mathrm{IC}_{50}$ and $\mathrm{IC}_{75}$ values and for roots and shoots the strongest inhibitory effect had $\mathrm{Ni}$ (II) (Fig. 1). No significant differences were confirmed between $\mathrm{Cr}$ (III) and $\mathrm{Cr}$ (VI) adverse effects on V. sativa shoot growth. On the basis of these values, and their statistical evaluation, metals can be arranged in the following rank orders of inhibition: for roots: $\mathrm{Ni}(\mathrm{II})>\mathrm{Cr}(\mathrm{VI})>\mathrm{Cr}(\mathrm{III})$; for shoots: $\mathrm{Ni}(\mathrm{II})>\mathrm{Cr}(\mathrm{VI}) \geq \mathrm{Cr}$ (III). 


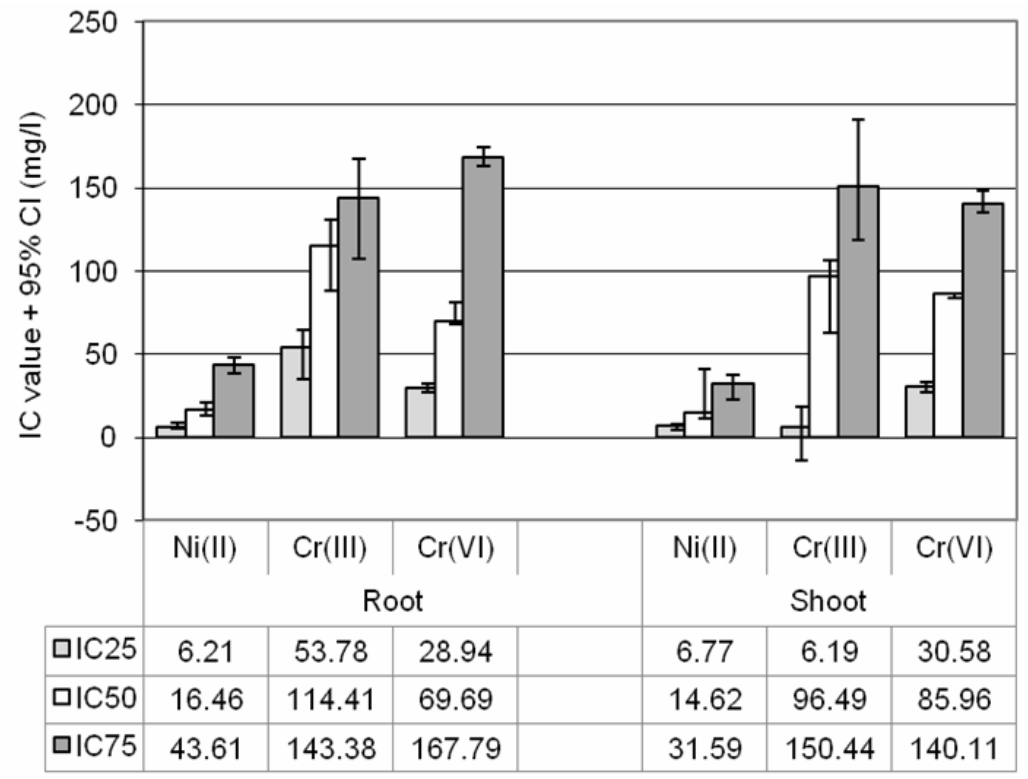

Fig. 1. $\mathrm{IC}_{25}, \mathrm{IC}_{50}$ and $\mathrm{IC}_{75}$ values and their $95 \%$ confidence intervals (CI) (ml/l) for Vicia sativa $\mathrm{L}$. after $72 \mathrm{~h}$ application; the mean of three determinations with a standard deviation $6 \%$ or less

For mutagenicity assay root tips of $V$. sativa were used and chromosome aberrations were determined at least in 500-anatelophases. All tested metals exerted in $V$. sativa a significant increase of chromosomal aberration rate in applied concentrations (Table 1). From all tested metals $\mathrm{Cr}(\mathrm{VI})$ invoked maximum of aberrations in anatelophase cells. The rank order of aberrations fall was: $\mathrm{Cr}(\mathrm{VI})>$ $\mathrm{Ni}(\mathrm{II})>\mathrm{Cr}(\mathrm{III})$.

Table 1. Potential clastogenicity evaluation of $\mathrm{Cr}$ and Ni in Vicia sativa L. $(\mathrm{n}=500)$

\begin{tabular}{|c|c|c|c|c|}
\hline \multirow{2}{*}{ Metal } & \multicolumn{2}{|c|}{ Metal concentration $(\mathrm{mg} / \mathrm{l})$} & \multirow{2}{*}{$\begin{array}{c}\text { Number of } \\
\text { aberrations } \pm \text { SD }\end{array}$} & \multirow{2}{*}{$\begin{array}{c}\text { Percentage of } \\
\text { aberrations } \pm \text { SD }\end{array}$} \\
\hline & $\mathrm{Ni}$ & $\mathrm{Cr}$ & & \\
\hline Control & $<0.07$ & $<0.01$ & $7 \pm 0.69$ & $2.33 \pm 0.23$ \\
\hline $\mathrm{Ni}(\mathrm{II})$ & $16.46 \pm 2.16$ & & $10 \pm 0.75 * *$ & $3.33 \pm 0.25 * *$ \\
\hline $\mathrm{Cr}$ (III & & $114.41 \pm 13.36$ & $8 \pm 0.75 *$ & $2.67 \pm 0.25 *$ \\
\hline $\mathrm{Cr}(\mathrm{VI})$ & & $69.69 \pm 8.66$ & $13 \pm 0.69 * *$ & $4.33 \pm 0.23 * *$ \\
\hline
\end{tabular}

$\mathrm{SD}$ - standard deviation; ** significant differences in comparison with control at $\mathrm{P}<0.01$; ${ }^{*}$ significant differences in comparison with control at $\mathrm{P}<0.05$; control - sterile distilled water

Genetic variation in susceptibility to environmental agents and metals can be considered as differences in metabolism of these agents in various organisms (OMENN, 1991). In addition, DNA target size and DNA content are also important in determining genotoxic hazard of metals. As described KOVALCHUK et al. (1998) and CHAUHAN et al. (1998) genotoxicity can be obtained as a result of multipolar anaphase and c-mitose or damage of protein synthesis in the presence of DNA 
toxicant. Simultaneous toxicity and clastogenity of wastes with $\mathrm{Cr}$ and $\mathrm{Ni}$ content was also confirmed for $V$. sativa by MIADOKOVÁ et al. (1999) and for V. faba and Allium cepa by Chandra et al. (2004; 2005). Chromozomal fragments and bridges created in $\mathrm{Cr}(\mathrm{VI})$ presence indicated as introduced QUIAN (2004) that $\mathrm{CrO}_{3}$ affecting DNA structure and conformation.

Table 2. Micronuclei frequency in the Tradescantia pollen tetrads after treatment with $\mathrm{Cr}$ and Ni solutions $(\mathrm{n}=1,500)$

\begin{tabular}{cccccc}
\hline \multirow{2}{*}{ Metal } & \multicolumn{2}{c}{ Metal concentration $(\mathrm{mg} / \mathrm{l})$} & & $\begin{array}{c}\text { Number of } \\
\text { micronuclues } \pm \mathrm{SD}\end{array}$ & $\begin{array}{c}\text { Percentage of } \\
\text { micronucleus } \pm \mathrm{SD}\end{array}$ \\
\cline { 2 - 3 } Control & $\mathrm{Ni}$ & $\mathrm{Cr}$ & $<0.01$ & & $43 \pm 13.74$ \\
$\mathrm{Ni}(\mathrm{II})$ & $24.71 \pm 0.25$ & & $59 \pm 17.48$ & $2.89 \pm 0.92$ \\
$\mathrm{Cr}(\mathrm{III}$ & & $130.00 \pm 1.30$ & & $47 \pm 16.61$ & $3.93 \pm 1.17$ \\
$\mathrm{Cr}(\mathrm{VI})$ & & $52.00 \pm 0.52$ & & $60 \pm 15.98$ & $3.13 \pm 1.11$ \\
\hline
\end{tabular}

SD - standard deviation

For determination of $\mathrm{Cr}$ and $\mathrm{Ni}$ genotoxic effects was also used analysis of micronuclei frequency in the pollen tetrads of Tradescantia plants. As it is evident from Table 2 none of tested metal significantly stimulated, in comparison with the control, micronuclei frequency and genotoxic effect was decreased in order: $\mathrm{Cr}(\mathrm{VI}) \geq$ $\mathrm{Ni}(\mathrm{II})>\mathrm{Cr}(\mathrm{III})$. Tradescantia micronucleus test (Trad-MCN) belongs together with Allium cepa L. and Vicia faba L. tests with root tips to most frequently used genotoxicity tests on plants (MAJER et al., 2005) and it is very popular now for in situ biomonitoring of air pollution (MIŠÍK et al., 2006; 2007). Results obtained during our genotoxicity tests are in good agreement with those introduced by KNASMÜLLER et al. (1998) when $\mathrm{CrO}_{3}, \mathrm{CrCl}_{3}$ and $\mathrm{NiCl}_{2}$ up to concentration $10 \mathrm{mM}$ did not evoke genotoxic effects. The same conclusion also introduced MAJER et al. (2005) for $\mathrm{Cr}$ (III). Higher genotoxicity of $\mathrm{Cr}(\mathrm{VI})$ than $\mathrm{Cr}$ (III) determined during our experiments also described NĚMEČEK et al. (2002). ROSSMAN (1995) introduced that molecular mechanism of DNA damage by $\mathrm{Cr}(\mathrm{VI})$ involve induction of DNA-DNA and DNAprotein cross-links and genotoxic effect can be also increased by reactive oxygen produced during intracellular reduction. For Ni(II) no genotoxic effects confirmed for bacteria ROSSMAN (1995) and PATIERNO and COSTA (1987) introduced that mutations after Ni applications are also the result of DNA damage and DNA-protein cross-links formation.

Acknowledgements This study was supported by grants VEGA 1/4361/07, VEGA 1/0238/08 and APVV - 0231-07.

\section{References}

BENNICELLI, R., STEPNIEWSKA, Z., BANACH, A., SZAJNOCHA, K., OSTROWSKI, J.: The ability of Azolla caroliniana to remove heavy metals ( $\mathrm{Hg}(\mathrm{II}), \mathrm{Cr}(\mathrm{III}), \mathrm{Cr}(\mathrm{VI}))$ from municipal waste water. Chemosphere, 55, 2004, 141 146. 
BROWN, P.H., WELCH, R.M., CARY, E.E.: Nickel: A micronutrient essential for higher plants. Plant Physiol., 85, 1987, 801-803

CHANDRA, S., CHAUHAN, L.K.S., PANDE, P.N., GUPTA, S.K.: Cytogenetic effects of leachates from tannery solid waste on the somatic cells of Vicia faba. Environ. Toxicol., 19, 2004, 129-133.

CHANDRA, S., CHAUHAN, L.K.S., MURTHY, R.C., SAXENA, P.N., PANDE, P.N., GUPTA, S.K.: Comparative biomonitoring of leachates from hazardous solid waste of two industries using Allium test. Sci. Total Environ., 347, 2005, 46-52.

CHAUHAN, L.K.S., SAXENA, P.N., SUNDARARAMAN, V., GUPTA, S.K.: Diuron-induced cytological and ultrastructural alterations in the root meristem cells of Allium cepa. Pestic. Biochem. Physiol., 62, 1998, 152-163.

KNASMÜllER, S., GOTTMANN, E., STEINKELLNER, H., FOMIN, A., PICKL, C., PASCHKE, A., GOD, R., KUNDI, M.: Detection of genotoxic effects of heavy metal contaminated soils with plant bioassays. Mutat. Res., 420, 1998, 37-48.

KOVALCHUK, O., KOVALCHUK, I., ARKHIPOV, A., TELYUK, P., HOHN, B., KOVALCHUK, L.: The Allium cepa chromosome aberration test reliably measures genotoxicity of soils of inhabited areas in the Ukraine contaminated by the Chernobyl accident. Mutat. Res., 415, 1998, 47-57.

KRISTEN, U.: Use of higher plants as screens for toxicity assessment. Toxicol. Vitro, 11, 1997, 181-191.

MA, T.H., CABRERA, G.L., CHEN, R., GILL, B.S., SANDHU, S.S., VANDERBERG, A.L., SALAMONE, M.F.: Tradescantia micronucleus bioassay. Environ. Health Perspect., 95, 1994, 157-189.

MAJER, B.J., GRUMMT, T., UHL, M., KNASMÜLLER, S.: Use of plant bioassays for the detection of genotoxins in the aquatic environment. Acta Hydrochim. Hydrobiol., 33, 2005, 45-55.

MIADOKOVÁ, E., DÚHOVÁ, V., VLČKOVÁ, V., SLÁDKOVÁ, L., SUCHÁ, V., VLČEK, D.: Genetic risk assessment of acid waste water containing heavy metals. Gen. Physiol. Biophys., 18, 1999, 92-98.

MIADOKOVÁ, E., SVIDOVÁ, S., VLČKOVÁ, V., DÚHOVÁ, V., PRAŽMÁRIOVÁ, E., TOTHOVÁ, K., NAĎOVÁ, S., KOGAN, G., RAUKO, P.: The role of natural biopolymers in genotoxicity of mutagens/carcinogens elimination. Biomed. Pap. Med. Fac. Univ. Palacky Olomouc Czech Rep., 149, 2005, 493-496.

MIČIETA, K., MURÍN, G.: Tree species of genus pinus suitable as bioindicators of polluted environment. Water Air Soil Pollut., 104, 1998, 413-422.

MIŠÍK, M., SOLENSKÁ, M., MIČIETA, K., MIŠÍKOVÁ, K., KNASMÜLLER, S.: In situ monitoring of clastogenicity of ambient air in Bratislava, Slovakia using the Tradescantia micronucleus assay and pollen abortion assays. Mutat. Res./Genet. Toxicol. Environ. Mutagen., 605, 2006, 1-6.

MIŠÍK, M., MIČIETA, K., SOLENSKÁ, M., MIŠÍKOVÁ, K., PISARČÍKOVÁ, H., KNASMÜLLER, S.: In situ biomonitoring of the genotoxic effects of mixed industrial emissions using the Tradescantia micronucleus and pollen abortion tests with wild life plants: Demonstration of the efficacy of emission controls in an eastern European city. Environ. Pollut., 145, 2007, 459-466. 
NĚMEČEK, J., PODLEŠÁKOVÁ, E., VÁCHA, R.: Transfer of trace elements with low soil mobility into plants. Rostl. Výr., 48, 2002, 45-50.

OMENN, G.S.: Future research direction in cancer ecogenetics. Mutat. Res., 247, 1991, 283-291.

PATIERNO, S.R., COSTA, M.: Effect of nickel II on nuclear protein binding in intact mammalian cells. Cancer Biochem. Biophys., 9, 1987, 113-126.

QUIAN, X.: Mutagenic effects of chromium trioxide on root tip cells of Vicia faba. J. Zhejiang Univ. Sci., 5, 2004, 1570-1576.

ROSSMAN, T.G.: Metal mutagenesis. In: R.A. GOYER, G.C. CHERIAN (Eds.) Toxicology of metals. Springer, New York, 1995, 373-430.

SHANKER, A.K., CERVANTES, C., LOZA-TAVERA, H., AVUDAINAYAGAM, S.: Chromium toxicity in plants. Environ. Int., 31, 2005, 739-753.

SHARMA, D.C., CHATTERJEE, C., SHARMA, C.P.: Chromium accumulation and its effects on wheat (Triticum aestivum L. c.v. Dh 2204) metabolism. Plant Sci., $111,1995,145-151$

SVETKOVÁ, K., FARGAŠOVÁ, A.: Phytotoxicity of washing waste waters from cutlery production line. Bull. Environ. Contam. Toxicol., 79, 2007, 109-113.

SZÁRAZOVÁ, K., FARGAŠOVÁ, A., HILLER, E., VELICKÁ, Z., PASTIEROVÁ, J.: Phytotoxic effects and translocation of $\mathrm{Cr}$ and $\mathrm{Ni}$ in washing wastewaters from cutlery production line to mustard (Sinapis alba L.) seedlings. Fresenius Environ. Bull., 17, 2008, 58-65. 